\title{
PELAYANAN BIMBINGAN DAN KONSELING ISLAM DALAM MENINGKATKAN KESEHATAN MENTAL PASIEN HIV/AIDS DI KLINIK VCT RUMAH SAKIT ISLAM SULTAN AGUNG SEMARANG
}

\author{
Noor Fu'at Aristiana, Baidi Bukhori, Hasyim Hasanah \\ Rumah Tahfidz Al Amna Kota Semarang \\ Email: ayaaristiana@gmail.com,baidi_bukhori1@yahoo.co.id, \\ hasyimhasanah_82@yahoo.co.id
}

\begin{abstract}
Abtract
This research is quantitative research to describe mental hygiene problems and to analyze islamic guidance and counseling to increase the healthiness of patient with HIV in VCT Clinic, Sultan Agung Hospital Semarang. The source of data in this research is counselor and patient with HIV. The method of collecting data use interview, observation, and documentation. The method analyze is interacive analyze model. The outcame from the research shows that, fisrt patient with HIV/AIDS have a mental hygiene problems. Second, islamic guidance and counseling services for them consist of pre test counseling, pasca test counseling, and sustainable counseling. Third, islamic guidance and counseling services to increase mental hygiene patient with HIV/AIDS focused on sefl-acceptance. To increase mental hygiene patient with HIV/AIDS required sustainable accompaniment about development and empowerment of the patient potential and family with HIV/AIDS
\end{abstract}

\begin{abstract}
$* * *$
Penelitian ini merupakan penelitian kualitatif yang bertujuan untuk mendiskripsikan problem kesehatan mental dan menganalisis pelayanan bimbingan dan konseling Islam dalam meningkatkan kesehatan mental pasien HIV/AIDS di Klinik VCT Rumah Sakit Islam Sultan Agung Semarang. Sumber data adalah konselor dan pasien HIV/AIDS. Metode pengumpulan data wawancara, observasi, dan dokumentasi. Metode analisis data model analisis interaktif. Hasil penelitian menunjukkan, pertama pasien HIV/AIDS memiliki problem kesehatan mental. Kedua, pelayanan bimbingan dan konseling Islam bagi penderita HIV/AIDS terdiri dari konseling pra tes, konseling pasca tes, dan konseling berkelanjutan. Ketiga, pelayanan bimbingan dan konseling Islam dalam meningkatkan kesehatan mental pasien HIV/AIDS ditekankan pada penerimaan diri.Untuk meningkatkan kesehatan mental pada diri pasien diperlukan pendampingan lanjutan tentang pengembangan dan pemberdayaan potensi korban dan keluarga dengan HIV/AIDS
\end{abstract}

Keywords: Islamic guidance and counseling, mental hygiene, and HIV/AIDS. 


\section{A. Pendahuluan}

Problematika kehidupan sosial mengakibatkan halal dan haram, dan yang haq ataupun yang bathil semakin susah dibedakan. ${ }^{1}$ Salah satu persoalan hubungan seksual di luar nikah (perzinaan), sebagai kebebasan seks (sex freedom) dan hak asasi manusia (human right), sepanjang hubungan seksual dilakukan orang dewasa tanpa paksaan (bukan perkosaan dan bukan dengan anak di bawah umur). Semakin banyaknya hubungan seksual di luar nikah (perzinaan) berdampak pada penyimpangan mental, gangguan kesehatan masyarakat, serta penyakit sosial lainnya akan muncul dan berujung pada runtuhnya peradaban. Saat ini penyakit yang muncul dari faktor penyimpangan seksual dan paling membahayakan serta menakutkan banyak orang adalah Human Immunodeciency Virus (HIV)/Acquire Immune Deficiency Syndrome (AIDS). HIV/AIDS sampai sekarang belum juga ditemukan obatnya. ${ }^{2}$

HIV merupakan suatu penyakit menular yaitu penyakit yang dapat berpindah dari satu orang ke orang yang lain, baik secara langsung maupun tidak langsung. Penyakit menular ini ditandai dengan adanya agen atau penyebab penyakit yang hidup dan dapat berpindah. ${ }^{3} \mathrm{HIV}$ merupakan virus yang menyebabkan tumbuh mencapai AIDS, tertular melalui darah, cairan sperma, dan cairan vagina. ${ }^{4}$ Penyebaran HIV pada seseorang sebagian besar melalui perzinaan (seks bebas dalam pelacuran), transfusi darah, jarum suntik yang tercemar, serta bayi dalam kandungan melalui tali pusar ibunya yang sudah mengidap HIV. ${ }^{5}$

Reaksi dari pasien ketika mengetahui terkena HIV/AIDS sangat bervariasi, mulai dari shock, stres, cemas, ketegangan batin, emosional, putus asa, takut, merasa harga diri rendah, ketidakberdayaan, dan sebagainya (Naing, 2004: 3). Reaksi lain berupa penolakan setelah menerima hasil tes reaktif atau positif. Penolakan terjadi karena merasa tidak mungkin terkena HIV/AIDS, merasa bahwa dirinya orang baik-baik dan tidak pernah melakukan hal-hal menyimpang yang mengarah pada terkenanya HIV/AIDS. Orang dengan HIV/AIDS (ODHA) merasa tidak

1 Dadang Hawari, Konsep Agama (Islam) Menaggulangi HIV/AIDS, (Yogyakarta: Dana Bhakti Primayasa, 2002), hlm. 13

2 Marzuki Umar Sa'abah, Ibid, hlm. 15

3 Lidya Maryani dan Riski Muliani, Epidemiologi Kesehatan Pendekatan Penelitian, (Yogyakarta: Grahana Ilmu, 2010), hlm. 71

${ }^{4}$ Syaiful W. Harahap, Pers Meliput AIDS, (Jakarta: Pustaka Sinar Harapan, 2000), hlm.

5 Dadang Hawari, Konsep Agama (Islam) Menaggulangi HIV/AIDS, (Yogyakarta: Dana Bhakti Primayasa, 2002), hlm. 96 
memiliki pandangan hidup ke depan serta beranggapan bahwa bunuh diri adalah hal yang terbaik. ${ }^{6}$ Reaksi lain munculnya sanksi atau tekanan sosial dari masyarakat. Harahap menjelaskan beberapa perlakuan masyarakat terhadap orang dengan HIV/AIDS yang selanjutnya disebut ODHA, di antaranya yaitu; pertama, diusir dan dikucilkan masyarakat; kedua, pemulangan ODHA dari satu daerah ke kampung halamannya; ketiga, dikarantina; keempat, diburu agar tidak melakukan praktik; dan, kelima permasalahan hak asasi tentang hidup dan mati. ${ }^{7}$ Hal demikian bukan hanya membuat ODHA sakit dari segi fisik, tetapi juga mengalami sakit pada segi mentalnya karena perlakuan masyarakat di sekitar dan beban mental yang dihadapinya. Jika gangguan-gangguan emosional dan ketegangan batin terjadi terus-menerus, maka hal demikian akan menimbulkan kesehatan mental ODHA semakin terganggu. ${ }^{8}$

Biasanya individu dengan ODHA mengalami ketidaksehatan mental. ${ }^{9}$ Ketidaksehatan mental disebabkan ketidakmampuan menyesuaikan diri, kegagalan, dan tekanan perasaan.10 Agar orang dengan HIV/AIDS dapat menjalani kehidupan dengan baik, maka diperlukan pendamapingan, penerimaan, support, dan dukungan mental. Dukungan keluarga, pasangan, teman sangat diperlukan bagi mereka yang mempunyai isu HIV untuk membantu mencapai kesehatan mental.11 Salah satu upaya yang diduga dapat membantu menangani problem kesehatan mental yang dihadapi ODHA dengan bimbingan dan konseling Islam. Bimbingan dan konseling Islam pada ODHA diarahkan pada pengembangan potensi diri untuk menciptakan lingkungan yang positif sebagai salah satu upaya preventive (pencegahan), curative (penyembuhan), dan developmental (pengembangan). ${ }^{12}$ Proses selanjutnya mengarahkan cara berpikir individu yang terkena HIV/AIDS agar mereka dapat menerima kenyataan, menumbuhkan semangat hidup, ikhlas, sabar, dan menjalani kehidupannya lebih baik

\footnotetext{
${ }^{6}$ Wawancara dengan Konselor VCT Khusnul Khotimah, tanggal 1 September 2015

7 Syaiful W. Harahap, Pers Meliput AIDS, (Jakarta: Pustaka Sinar Harapan, 2000), hlm. 126-144

${ }^{8}$ Kartini Kartono, Hygiene Mental, Bandung: Mandar Maju, 2000) hlm. 21

${ }^{9}$ Yustinus Semiun, Kesehatan Mental 1, (Yogyakarta: Kanisius, 2006), hlm. 9

10 Zakiah Daradjat, Pendidikan Agama dalam Pembinaan Mental, (Jakarta: Bulan Bintang, 1982), hlm. 103

${ }^{11}$ Amaya Maw Naing, dkk, Modul Pelatihan Konseling dan Tes Sukarela HIV (Voluntary Conseling and Test/VCT) untuk konselor profesional, Departemen Kesehatan RI (Direktoral Jendral Pelayanan Medik Direktorat Jendral Pemberantasan Penyakit Menular dan Penyakit Lingkungan, 2004), hlm. 5

12 Thohar Musnamar, Dasar-Dasar Konseptual Bimbingan dan Konseling Islam, (Yogyakarta: UII Press, 1992), hlm. 4
} 
untuk mendapatkan kebahagiaan di dunia dan akhirat ketika nanti waktunya tiba, sehingga tercapailah kembali kesehatan mental. Kondisi kesehatan mental ditandai dengan ketenangan, ketentraman, dan berkurangnya perasaan bersalah. Orang dengan HIV/ AIDS dengan bimbingan konseling Islam cenderung lebih memiliki penerimaan diri secara positif dan dalam kondisi mental sehat.

Salah satu unit kesehatan yang memiliki konsen luar biasa dalam memberikan layanan bimbingan dan konseling Islam terhadap pasien dengan HIV/AIDS adalah Rumah Sakit Islam Sultan Agung Semarang (yang selanjutnya disebut RSISA). RSISA melalui klinik VCT memberikan pelayanan dampingan secara terstruktur dan holistik bagi orang dengan HIV/AIDS agar memiliki mental yang sehat dalam menjalani penyakitnya. Diraihnya akreditasi, menuntut RSISA tidak hanya meningkatkan mutu pelayanan bidang medis tetapi juga pelayanan non medis. Komitmen ini diwujudkan dengan pemberian layanan bimbingan dan konseling Islam kepada orang dengan HIV/AIDS secara terstruktur dan intensif. Penelitian ini selanjutnya berupaya menjelaskan problem-problem kesehatan mental dan pelayanan Bimbingan dan Konseling Islam dalam meningkatkan kesehatan mental pasien HIV/AIDS di Klinik VCT RSI Sultan Agung Semarang.

\section{B. Kerangka Konseptual}

\section{Kesehatan Mental Pasien HIV/AIDS}

Para ahli berbeda pendapat mengenai pengertian kesehatan mental. Langgulung menjelaskan bahwa kesehatan mental adalah keselamatan dan kebahagiaan yang berlaku di dunia dan menurut pandangan Islam kebahagiaan di dunia hanyalah jalan ke arah kebahagiaan akhirat, sedang kebahagiaan akhirat tidak dapat dicapai tanpa usaha di dunia. ${ }^{13}$ Daradjat juga menjelaskan, kesehatan mental sebagai suatu kondisi terhindar dari gangguan dan penyakit kejiwaan, mampu menyesuaikan diri, sanggup menghadapi masalah-masalah dan goncangan-goncangan biasa, adanya keserasian fungsi-fungsi (tidak ada konflik) dan merasa bahwa dirinya berharga, berguna, dan bahagia, serta dapat menggunakan potensi yang ada padanya seoptimal mungkin. ${ }^{14}$ Berbeda dengan Langgulung dan

13 Hasan Langgulung, Teori-Teori Kesehatan Mental, (Jakarta: Pustaka Al-Husan, 1686), hlm. 444

14 Zakiah Daradjat, Islam dan Kesehatan Mental, (Jakarta: CV. Haji Masagung, 1988), hlm. 82-83 
Daradjat, Kartono dan Andari mengartikan kesehatan mental adalah bagaimana cara orang memecahkan segenap keruwetan batin manusia yang ditimbulkan oleh macam-macam kesulitan hidup, serta berusaha mendapatkan kebersihan jiwa, dalam pengertian tidak terganggu oleh macam-macam ketegangan, kekalutan dan konflik terbuka serta konflik batin..$^{15}$ Kesehatan mental menurut pandangan penulis adalah terwujudnya keharmonisan dan keserasian jiwa dalam menghadapi masalah dan dapat memecahkan segala macam persoalan, sehingga memunculkan kebahagiaan dalam diri.

Belum semua orang memiliki kesehatan mental, kondisi ini disebut gangguan mental, gangguan mental dipengaruhi beberapa aspek, yaitu; perasaan, pikiran, kelakuan, dan kesehatan tubuh. Gangguan perasaan berupa rasa cemas, takut, iri-dengki, sedih tidak berasalan, marah oleh halhal remeh, bimbang merasa diri rendah, sombong, tertekan (frustasi), pesimis, putus asa, apatis, dan sebagainya. Pikiran berupa kemampuan berpikir berkurang, sukar memusatkan perhatian, mudah lupa, tidak dapat melanjutkan rencana yang telah dibuat. Kelakuan berupa tindakan nakal, pendusta, menganiaya diri atau orang lain, menyakiti badan orang atau hatinya, dan berbagai kelakuan menyimpang lainnya. Kesehatan tubuh misalnya; penyakit jasmani yang tidak disebabkan oleh gangguan pada jasmani. ${ }^{16}$

Sutadipura menjelaskan empat faktor di atas: pertama, perasaan yaitu dalam perasaan yang selamanya terganggu (tertekan), tidak tenteram, rasa gelisah tidak menentu, tidak bisa pula mengatasinya, berperasaan takut yang tidak masuk akal atau tidak jelas apa yang ditakuti, merasa iri, rasa sombong, suka bergantung kepada orang lain, tidak mau bertanggung jawab dan lain-lain. Kedua, pikiran memiliki peranan penting dalam menggangu kesehatan mental, demikian pula mental dapat mempengaruhi pikiran. Ketiga, kelakuan yaitu terganggunya kesehatan mental biasanya ditandai dengan senangnya berkelakuan tidak baik, seperti; kenakalan, keras kepala, suka berdusta, menipu, menyeleweng, mencuri, menyiksa orang lain, dan lain-lain. Keempat, kesehatan jasmani juga dapat terganggu, hal ini terjadi bukan karena fisiknya langsung, akan tetapi perasaannya akibat dari jiwa yang tidak tenteram. ${ }^{17}$

15 Kartini Kartono dan dr. Jenny Andari, Hygine Mental dalam Islam, (Bandung: CV. Mandar Maju, 1989), hlm. 4

16 Zakiah Daradjat, Islam dan Kesehatan Mental, (Jakarta: CV. Haji Masagung, 1988), hlm. 9

17 Balnadi Sutadipura, Kompetensi Guru dan Kesehatan Mental, (Bandung: CV. Angkasa, 1986) hlm. 55-56 
Berangkat dari penjelasan kesehatan mental yang berbeda-beda sesuai dengan bidang dan pandangan masing-masing, maka upaya pencapaiannya juga beragam. Kartono berpendapat ada tiga prinsip pokok untuk mendapatkan kesehatan mental, pertama, pemenuhan kebutuhan pokok. Kedua, kepuasan yaitu setiap orang menginginkan kepuasan, baik yang bersifat jasmaniah maupun yang bersifat psikis. Ketiga, posisi dan status sosial yaitu setiap individu selalu berusaha mencari posisi sosial dan status sosial dalam lingkungannya. ${ }^{18}$

Sangat sulit untuk menetapkan satu ukuran dalam menentukan dan menafsirkan kesehatan mental. Upaya-upaya yang dilakukan individu untuk mencapai kesehatan mental diperlukan indikator, untuk mengukur kesehatan mental pada individu. Alexander A. Schneiders dalam Semiun menjelaskan indikator dalam kesehatan mental, yaitu: efisiensi mental merupakan penggunaan kapasitas secara efektif dalam mengamati, membayangkan, belajar, berpikir, memilih, dan juga mengembangkan terus menerus fungsi-fungsi mental sampai suatu tingkat efisiensi yang lebih tinggi; pengendalian, integrasi pikiran, dan tingkah laku; integrasi motifmotif serta pengendalian konflik dan frustasi; perasaan-perasaan dan emosi-emosi yang positif serta sehat; ketenangan atau kedamaian pikiran; sikap-sikapyang sehat; konsep diri yang sehat; serta identitas ego yang kuat. ${ }^{19}$

Indikator di atas dirasa paling tepat untuk mengukur kesehatan mental dalam penelitian ini, karena dalam indikator diatas mencakup beberapa reaksi yang berhubungan dengan mental seseorang. Seseorang dapat mengetahui apakah dirinya memiliki kesehatan mental yang baik atau terjadi gangguan pada kesehatan mentalnya.

\section{Bimbingan dan Konseling Islam}

Bimbingan dan Konseling berasal dari bahasa Inggris guidance dan counseling. Bimbingan dan konseling memiliki banyak pengertian. Ada pendapat bahwa konseling sebagai teknik bimbingan. Bimbingan memusatkan diri pada pencegahan munculnya masalah, sedangkan konseling memusatkan diri pada pemecahan masalah yang dihadapi individu. ${ }^{20}$ Bimbingan dan konseling memiliki persamaan dan perbedaan

18 Kartini Kartono dan dr. Jenny Andari, Hygine Mental dalam Islam, (Bandung: CV. Mandar Maju, 1989), hlm. 29-30

19 Yustinus Semiun, Kesehatan Mental 1, (Yogyakarta: Kanisius, 2006), hlm. 52-55

20 Thohar Musnamar, Dasar-Dasar Konseptual Bimbingan dan Konseling Islam, (Yogyakarta: UII Press, 1992), hlm. 3 
antara keduanya. Bimbingan diambil dari bahasa Inggris guidance dikaitkan dengan kata asal guide, yang diartikan sebagai berikut: menunjukkan jalan (giving instruction); mengatur (regulating); mengarahkan (governing); memberikan nasihat (giving advice).

Bimbingan menurut Winkel dan Hastuti merupakan pemberian informasi, menyajikan pengetahuan yang dapat digunakan untuk mengambil suatu keputusan, atau memberitahukan sesuatu dengan memberikan nasihat; dan mengarahkan, menuntut ke suatu tujuan. Tujuan itu mungkin hanya diketahui oleh pihak yang mengarahkan, atau mungkin perlu diketahui oleh kedua belah pihak. ${ }^{21}$ Berbeda dengan Waligito bimbingan merupakan pemberian pertolongan dan bantuan. Bimbingan dan pertolongan merupakan hal yang pokok. Bimbingan dapat diberikan secara individu dan juga dapat secara kelompok. Bimbingan dapat diberikan baik untuk menghindari kesulitan-kesulitan maupun untuk mengatasi persoalan-persoalan yang dihadapi individu-individu di dalam kehidupannya. ${ }^{22}$

Berdasarkan penjelasan di atas dapat disimpulkan bahwa bimbingan adalah bantuan atau pertolongan yang diberikan kepada individu atau sekumpulan individu dalam menghindari atau mengatasi kesulitankesulitan di dalam kehidupannya, agar dapat mencapai kesejahtraan hidupnya.

Adapun istilah konseling berasal dari kata conseling yang berasal dari kata to counsel, sedangkan secara etimologi berarti to giving advice atau memberi saran dan nasihat. Konseling juga memiliki arti memberikan nasihat atau memberikan anjuran kepada orang lain secara tatap muka. ${ }^{23}$ Istilah konseling juga selalu dirangkaikan dengan istilah bimbingan. Bimbingan dan konseling merupakan suatu kegiatan yang integral. ${ }^{24}$ Prayitno dan Amti mengartikan, konseling sebagai proses pemberian bantuan yang dilakukan melalui wawancara oleh seorang ahli (disebut konselor) kepada individu sedang mengalami suatu masalah (disebut klien) sehingga bermuara pada teratasinya masalah yang dihadapi oleh klien. 25

21 Winkel dan Sri Hastuti, Bimbingan dan Konseling di Institusi Pendidikan, (Yogyakarta: Media Abadi, 2007), hlm. 27

22 Bimo Waligito, Bimbingan dan Konseling (Studi \& Karir), (Yogyakarta: ANDI, 2004), hlm. 4-5

${ }^{23}$ Samsul Munir Amin, Bimbingan dan Konseling Islam, (Jakarta: AMZAH, 2010), hlm. 10-11

${ }^{24}$ A. Hallen, Bimbingan dan Konseling, (Jakarta: Quantum Teaching, 2005), hlm. 9

25 Prayitno dan Erman Amti, Dasar-Dasar Bimbingan dan Konseling, (Jakarta: Rineka Cipta, 1999), hlm. 105 
Konseling merupakan salah satu teknik dalam pelayanan bimbingan di mana proses pemberian bantuan itu berlangsung melalui wawancara dalam serangkaian pertemuan langsung dan tatap muka antara guru pembimbing/konselor dengan klien, dengan tujuan agar klien mampu memperoleh pemahaman lebih baik terhadap dirinya untuk mengembangkan potensi yang dimiliki ke arah perkembangan optimal, sehingga dapat mencapai kebahagiaan pribadi dan kemanfaatan sosial. ${ }^{26}$

Berdasarkan penjelasan di atas dapat disimpulkan, konseling adalah proses pemberian bantuan terhadap individu dalam hal mengembangkan potensi, serta dapat menanggulangi problematika hidup dan kehidupannya, dan membantu individu agar menyadari kembali akan keberadaannya sebagai makhluk Allah yang seharusnya hidup selaras dengan ketentuan dan petunjuk Allah yang berpedoman kepada Al Quran dan As Sunnah untuk mencapai kebahagiaan dunia dan akhirat.

Pengertian bimbingan dan konseling secara terpisah telah dijelaskan, maka akan dijelaskan bimbingan dan konseling Islam secara kesatuan. Sutoyo menjelaskan bahwa hakikat bimbingan dan konseling Islam adalah upaya membantu individu belajar mengembangkan fitrah dan atau kembali pada fitrah, dengan cara memberdayakan (empowering) iman, akal, dan kemauan yang diturunkan Allah swt. kepadanya untuk mempelajari tuntunan Allah dan Rasul-Nya, agar fitrah yang ada pada individu berkembang dengan benar dan kokoh sesuai tuntunan Allah swt. ${ }^{27}$

Berdasarkan uraian di atas dapat diambil kesimpulan, bahwa bimbingan dan konseling Islam adalah proses membantu individu yang sedang bermasalah, dengan mengembangkan fitrah atau kembali pada fitrah, memberdayakan iman, akal, dan kemauan yang diturunkan Allah swt, sehingga dapat mengembangkan potensinya dan dapat menyelesaikan masalah, dengan tujuan mendapatkan kebahagiaan di dunia dan akhirat. Fungsi bimbingan dan konseling secara umum adalah sebagai fasilitator dan motivator klien dalam upaya mengatasi dan memecahkan problem kehidupan klien dengan kemampuan yang ada pada dirinya sendiri. ${ }^{28}$ Faqih menjelaskan fungsi dari bimbingan dan konseling Islam, yaitu: pertama, fungsi preventif yakni membantu individu menjaga atau mencegah timbulnya masalah bagi dirinya. Kedua, fungsi kuratif atau korektif, yakni membantu individu memecahkan masalah yang sedang dihadapi atau

${ }^{26}$ A. Hallen, Bimbingan dan Konseling, (Jakarta: Quantum Teaching, 2005), hlm. 11

27 Anwar Sutoyo, Bimbingan dan Konseling Islam Teori dan Praktik, (Semarang: Widya Karya, 2009), hlm. 23

${ }^{28}$ Samsul Munir Amin, Bimbingan dan Konseling Islam, (Jakarta: AMZAH, 2010), hlm. 44 
dialaminya. Ketiga, fungsi preserfatif yaitu membantu individu menjaga agar situasi dan kondisi yang semula tidak baik (mengandung masalah) menjadi baik (terpecahkan) dan kebaikan itu bertahan lama. Keempat, fungsi development atau pengembangan yakni membantu individu memelihara dan mengembangkan situasi dan kondisi yang telah baik agar tetap baik atau menjadi lebih baik, sehingga tidak memungkinkannya menjadi sebab munculnya masalah baginya. ${ }^{29}$

Tujuan yang ingin dicapai melalui bimbingan dan konseling Islam adalah agar fitrah yang dikaruniakan oleh Allah kepada individu dapat berkembang dan berfungsi dengan baik, sehingga menjadi pribadi yang kaaffah, dan secara bertahap mampu mengaktualisasikan apa yang diimaninya dalam kehidupan sehari-hari, tampil dalam bentuk kepatuhan terhadap hukum-hukum Allah dalam melaksanakan tugas kekhalifahan di bumi, dan ketaatan dalam beribadah dengan mematuhi segala perintahNya dan menjauhi segala larangan-Nya. Tujuan konseling model ini dengan kata lain adalah meningkatkan iman, Islam, dan ikhsan individu yang dibimbing hingga menjadi pribadi yang utuh. Bimbingan pada akhirnya diharapkan mampu mengantar hidup bahagia di dunia dan akhirat. ${ }^{30}$ Menurut Amin, tujuan bimbingan dan konseling Islam juga menjadi tujuan dakwah Islam. Karena dakwah yang terarah adalah memberikan bimbingan kepada umat Islam untuk mencapai dan melaksanakan keseimbangan hidup di dunia dan akhirat. Bimbingan dan konseling Islam dengan demikian merupakan bagian dari dakwah Islam. ${ }^{31}$

\section{Individu Dengan HIV/AIDS}

Penyakit HIV/AIDS di Indonesia pada saat ini semakin meningkat. HIV/AIDS merupakan penyakit menular. Harahap menjelaskan dalam buku "Pers meliput AIDS" bahwa istilah Acqure Immune Deficiency Syndrome (AIDS) dari segi medis merupakan kumpulan gejala-gejala penyakit yang diidap oleh seseorang yang sudah terinfeksi Human Immunodeciency Virus (HIV). AIDS juga diartikan sebagai sindrome cacat

${ }^{29}$ Ainur Rahim Faqih, Bimbingan dan Konseling dalam Islam, (Jogjakarta: UII Press, 2001), hlm. 37

${ }^{30}$ Anwar Sutoyo, Bimbingan dan Konseling Islam Teori dan Praktik, (Semarang: Widya Karya, 2009), hlm. 205

31 Samsul Munir Amin, Bimbingan dan Konseling Islam, (Jakarta: AMZAH, 2010), hlm. 40 
kekebalan tubuh, yang berarti AIDS bukan penyakit keturunan tetapi karena sistem kekebalan tubuh dirusak setelah seseorang terinfeksi. ${ }^{32}$

HIV adalah sebuah virus yang menyebabkan terjadinya AIDS. AIDS tidak menular, yang menular adalah HIV. AIDS merupakan gejala yang ditimbulkan dari HIV. HIV dapat menular dari beberapa cara, yaitu: seks bebas, melalui transfusi darah orang yang terkena HIV, jarum suntik yang tercemar HIV, dan bayi dalam kandungan melalui tali pusar ibunya yang mengidap HIV. Dampak dari HIV/AIDS tidak hanya pada segi fisik saja, tetapi juga pada respons adaptif psikologis atau yang disebut dengan penerimaan diri yang mengakibatkan munculnya berbagai reaksi dan perasaan yang muncul pada diri ODHA. Tahapan penerimaan diri ODHA yaitu: shock (kaget dan goncangan batin); mengucilkan diri seperti merasa cacat, tidak berguna, dan menutup diri; membuka setatus secara terbatas seperti ingin tahu reaksi orang lain, pengalihan stres, dan ingin dicintai; mencari orang lain yang HIV/AIDS positif seperti berbagi rasa, pengenalan, kepercayaan, penguatan, dan dukungan sosial; status khusus seperti perubahan keterasingan menjadi manfaat khusus, perbedaan menjadi hal yang istimewa, dan dibutuhkan orang yang lainnya; perilaku mementingkan orang lain seperti komitmen dan kesatuan kelompok, kepuasan memberi dan berbagi, dan perasaan sebagai kelompok; penerimaan seperti integrasi status positif HIV dengan identitas diri, keseimbangan antara kepentingan orang lain dengan diri sendiri, bisa menyebutkan kondisi seseorang. 33

Ross juga menguraikan lima tahap reaksi emosi seseorang terhadap penyakitnya, yaitu: pengingkaran, kemarahan, sikap tawar menawar, depresi, serta penerimaan dan partisipasi. ${ }^{34}$ Pertama, pengingkaran (denial), pada tahap ini pasien menunjukkan karakteristik perilaku pengingkaran. Pengingkaran ini dapat disebabkan karena ketidaktahuan pasien terhadap sakitnya atau sudah mengetahuinya dan mengancam dirinya. Kedua, kemarahan (anger). Perilaku pasien secara karakteristik dihubungkan dengan rasa marah dan rasa bersalah. Pasien akan mengungkapkan kemarahannya pada diri sendiri, dan kemudian timbul penyesalan. Ketiga, sikap tawar menawar (bargaining). Setelah marahmarah, pasien akan berpikir dan merasakan bahwa protesnya tidak berarti. ODHA mulai timbul perasaan bersalah dan mulai membina hubungan

32 Syaiful W. Harahap, Pers Meliput AIDS, (Jakarta: Pustaka Sinar Harapan, 2000), hlm. 15

${ }_{33}$ Nursalam dan Ninuk Dian Kurniawati, Asuhan Keperawatan pada Pasien Terinfeksi HIV/AIDS, (Jakarta: Salemba Medika, 2009), hlm. 15

${ }^{34}$ Nursalam dan Ninuk Dian Kurniawati, Ibid, hlm. 15-17 
dengan Tuhan, yaitu mereka akan menjadi lebih baik. Keempat, depresi yaitu ODHA akan mengalami kesedihan, tidak berdaya, tidak ada harapan, merasa bersalah, penyesalan yang dalam, dan kesepian. Kelima, penerimaan dan partisipasi. Tahap ini pasien mulai beradaptasi, kepedihan yang dialami semakin berkurang dan bergerak menuju identifikasi sebagai seseorang yang mengalami keterbatasan karena penyakit dan sebagai seseorang yang cacat. ODHA selain mengalami respon seperti yang dijelaskan di atas, juga mengalami respons adaptif spiritual. Respon adaptif spiritual dikembangkan dari konsep Ronaldson, Kauman, dan Nipan yang meliputi harapan yang realistis, tabah dan sabar, serta dapat mengambil hikmah. ${ }^{35}$

\section{Analisis Hasil Temuan Penelitian}

\section{Pelayanan Bimbingan dan Konseling Islam di Klinik VCT RSI Sultan Agung Smarang}

RSI Sultan Agung merupakan rumah sakit tipe B pendidikan. RSI Sultan Agung yang terakreditasi B sehingga ditunjuk oleh pemerintah kota Semarang untuk melayani pasien-pasien terkena HIV/AIDS, baik yang rawat inap maupun rawat jalan. Pihak rumah sakit dengan demikian harus melaporkan jumlah kunjungan serta diagnosis pasien yang memeriksakan diri untuk tes HIV/AIDS kepada pemerintah provinsi dan pemerintah kota Semarang. Pada tanggal 14 September 2013 Direktur RSI Sultan Agung membentuk TIM pengendalian penyakit TB dan HIV/AIDS, yaitu pada klinik VCT. ${ }^{36}$

Klinik VCT merupakan suatu pembinaan dua arah atau dialog yang berlangsung tidak terputus antara konselor dan klien dengan tujuan untuk mencegah penularan HIV, memberikan dukungan moral, informasi, serta dukungan lainnya kepada ODHA, keluarga, dan lingkungan. Pelayanan VCT harus dilakukan oleh petugas yang terlatih dan berkualitas dalam melakukan konseling dan deteksi HIV. Hal ini penting mengingat terinfeksinya seseorang dengan HIV/AIDS akan berdampak pada kehidupan pada penderitanya dan orang-orang yang berinteraksi dengannya. Klinik VCT RSISA memiliki tiga konselor. Ketiga konselor tersebut adalah dr. Retno Triwulandari, M.Gz. sebagai dokter, Ns. Muh.

\footnotetext{
35 Nursalam dan Ninuk Dian Kurniawati, Ibid, hlm. 15-17

36 Wawancara dengan Report and Record Ziadah Mustafa, tanggal 1 September 2015
} 
Mahfud, S. Kep. sebagai perawat, dan Khusnul Khotimah, S.Pd. I, M.SI. sebagai bimbingan penyuluhan Islam (BPI). ${ }^{37}$

Konselor berperan dalam memberikan penjelasan tentang tes yang akan dilakukan dan mengajukan pilihan apakah pasien menyetujui diambil darahnya untuk dilakukan tes atau tidak. Konselor menjelaskan bahwa tes yang dilakukan untuk mengetahui virus yang merusak kekebalan tubuh pada diri pasien. Konselor dalam hal ini tidak menjelaskan bahwa virus tersebut adalah HIV/AIDS, karena mereka akan berpikir bahwa HIV/AIDS merupakan hal yang mengerikan apalagi bagi mereka yang nantinya memiliki hasil positif, pasti akan memiliki masalah-masalah yang terjadi pada dirinya. ${ }^{38}$

Pasien yang telah melakukan tes dan hasilnya positif mengalami masalah-masalah pada dirinya. Masalah yang dialami tidak hanya dari segi fisik saja, tetapi mereka juga mengalami masalah pada segi psikis. Masalah pada segi psikis ODHA akan menyebabkan kesehatan mental pada dirinya terganggu. Masalah tersebut di antarannya yaitu efisiensi mental yang terganggu, sulit mengendalikan diri, mengalami kejenuhan, perasaan negatif dan tanggapan negatif dari masyarakat, serta tidak menerima diri dan putus asa. Pertama, ODHA mengalami efisiensi mental terganggu merasa dirinya tidak berharga. ODHA di klinik VCT RSISA mengalami efesiensi mental berupa merasa dirinya tidak berharga serta merasa tidak berdaya untuk menghadapi penyakit yang ada pada dirinya. Kedua, sulit mengendalikan diri, merasa kaget dan tidak percaya bahwa dirinya tertular HIV/AIDS. Hal ini menjadikan ODHA membutuhkan integrasi pikiran dan tingkah laku agar dapat menerima serta bisa menyesuaikan dirinya dengan penyakit yang diderita agar dapat menjalani hidup lebih baik. ${ }^{39}$

Ketiga, ODHA mengalami kejenuhan, karena dia harus meminum obat setiap hari untuk menekan pertumbuhan virus yang ada dalam tubuh, meskipun demikian penyakit yang ada pada dirinya hingga sekarang belum bisa disembuhkan. ${ }^{40}$ Keempat, ODHA pada awalnya dalam menjalani hidupnya memiliki perasaan-perasaan negatif, selain itu tanggapan negatif masyarakat yang dapat mengganggu atau bahkan merusak kestabilan emosi. Gangguan emosi seperti perasaan tidak aman, merasa bersalah, rendah diri, merasa benci dengan orang yang menulari, merupakan tandatanda yang dapat menyebabkan kesehatan mental pada ODHA terganggu. ${ }^{41}$

\footnotetext{
37 Wawancara dengan Report and Record Ziadah Mustafa, tanggal 6 Juni 2015

38 Wawancara dengan Konselor VCT Khusnul Khotimah, tanggal 1 September 2015

39 Wawancara dengan Konselor VCT Khusnul Khotimah, tanggal 15 September 2015

40 Wawancara dengan Konselor VCT Khusnul Khotimah, tanggal 15 September 2015

${ }^{41}$ Wawancara dengan Konselor VCT Khusnul Khotimah, tanggal 15 September 2015
} 
Sebagian ODHA merasa tenang-tenang saja, seperti yang dialami Bapak P, dia adalah seorang petani. Dia merupakan orang yang baik, polos, suka menolong orang, dan tidak pernah melakukan hal-hal menyimpang yang mengakibatkan dirinya berisiko terkena HIV/AIDS. Bapak P mengeluh sakit dengan tanda beresiko terkena HIV/AIDS, kemudian menjalani tes. Hasil tes menunjukkan bahwa dia positif HIV, ketika mengetahui bahwa dirinya HIV positif reaksinya tenang saja karena dia memang tidak tahu tentang HIV/AIDS. ${ }^{42}$ Kelima, banyak mereka yang tidak menerima diri dan putus asa atas penyakitnya. ${ }^{43}$ Hasil penelitian menunjukkan tidak semuanya ODHA larut dalam masalah dan memiliki perasaan negatif. Pengalaman dan pendidikan pengetahuan tentang HIV/AIDS menjadi faktor perbedaan respon. ODHA meskipun awalnya mengalami penolakan, tapi ada sebagian dari mereka bisa menerima dan mengambil hikmah dari sakitnya. Pasien ketika mengetahui dirinya terkena HIV/AIDS cenderung mengalami goncangan batin, mengalami masalah psikis, meskipun ada sebagian ODHA yang bisa menerima. Faktor yang mempengaruhi kesehatan mental ODHA seperti tanggapan orang-orang di sekitarnya, motivasi orang-orang terdekat, pendidikan, pengalaman, serta karakter bawaan ODHA. Faktor lain adalah konselor. Konselor HIV/AIDS perlu memiliki metode khusus pemberian pelayanan konseling. Metode layanan bimbingan dan konseling Islam mulai dari tahap awal, tahap inti, tahap akhir, kemudian dilakukan analisis bersama antara pasien dengan konselor. Langkah selanjutnya apa yang akan dipikirkan serta merencanakan hal apa yang akan dilakukan dengan peningkatan kualitas hidup pasien HIV/AIDS.

Konseling pada pasien HIV/AIDS di klinik VCT RSISA memiliki beberapa tahap, yaitu: konseling permulaan, konseling pra tes, konseling pasca tes, dan konseling berkelanjutan:44 Pertama, konseling permulaan. Konseling dilakukan dengan tujuan untuk memberikan arahan kepada individu yang dirasa memerlukan tes HIV. Individu yang memerlukan tes misalnya pasien sakit batuk dalam jangka waktu lama dan pasien TB yang sudah dirawat tapi tidak mencapai kesembuhan. Tujuan dari konseling ini yaitu agar pasien memahami kegunaan tes tersebut, pasien dapat menilai resiko dan mengerti persoalan dirinya, pasien dapat menurunkan kecemasan, dapat membuat rencana penyesuaian diri dalam kehidupan, serta dapat memilih dan memahami apakah akan melakukan tes darah atau tidak.

\footnotetext{
42 Wawancara dengan Konselor VCT Khusnul Khotimah, tanggal 15 September 2015 43 Wawancara dengan Konselor VCT Khusnul Khotimah, tanggal 15 September 2015

44 Wawancara dengan Report and Record Ziadah Mustafa, tanggal 1 September 2015
} 
Kedua, konseling pra tes. Konseling pra tes dilakukan secara individu dengan pasien. Konseling dilakukan dengan adanya persetujuan dari pasien. Konseling bertujuan membantu pasien mempersiapkan diri untuk pemeriksaan serta memberikan dukungan pada pasien, apapun hasil tes pasien harus bisa menerima dan mengembalikan semua pada Allah swt. Ketiga, konseling pasca tes. Konseling pasca tes merupakan kegiatan konseling yang harus diberikan setelah hasil tes diketahui, baik hasilnya positif maupun negatif. Konseling pasca tes ada dua macam, yaitu untuk hasil yang non reaktif (negatif) dan hasil reaktif (positif). Konseling pasca tes bagi pasien dengan hasil non reaktif bertujuan untuk mengarahkan agar pasien tidak melakukan atau menjaga dari hal yang menyimpang atau berpotensi untuk tertularnya penyakit HIV/AIDS. Pasien yang memiliki hasil non reaktif bukan berarti dirinya tidak tertular atau bersih dari HIV/AIDS, tes akan dilakukan lagi setelah tiga bulan, karena dikhawatirkan ketika tes pertama terjadi periode jendela. Periode jendela yaitu masa antara masuknya HIV ke dalan tubuh hingga terbentuknya antibodi (zat tubuh untuk menangkal penyakit) terhadap HIV. Fase ini dapat menularkan HIV kepada orang lain meskipun hasil tesnya masih negatif. Tes ini dilakukan kurang lebih selama satu tahun. Tujuan konseling bagi mereka yang memiliki hasil negatif yaitu: agar pasien dapat memahami arti periode jendela, pasien dapat membuat keputusan akan tes ulang atau tidak, serta kapan waktu yang tepat untuk mengulang, dan memberikan pedoman bagi pasien untuk mengurangi resiko melalui perilakunya.

Konseling pasca tes pasien dengan hasil reaktif diberikan dengan tujuan untuk memberikan dukungan dan mendampingi pasien agar dapat menerima dengan ikhlas, sabar, berserah diri kepada Allah; memahami dan menerima hasil tes secara tepat, menurunkan masalah psikis dan emosi karena hasil tes; agar pasien dapat menyesuaikan kondisi dirinya dengan infeksi serta menyusun pemecahan masalah, memperbaiki hidup dengan lebih baik, dan memberikan bimbingan agar tidak menularkan pada orang lain.

Keempat, konseling berkelanjutan. Konseling berkelanjutan bertujuan untuk memfasilitas ODHA. Mereka dapat menceritakan apa yang dialami serta keluhan yang dirasakan. Pasien dengan hasil reaktif akan ditindak lanjuti dengan pengobatan. Pengobatan yang dilakukan pasien HIV/AIDS dilakukuan seumur hidup, karena belum ada obat untuk menyembuhkan pasien HIV/AIDS. Pengobatan yang dilakukan oleh ODHA hanya bertujuan untuk menekan pertumbuhan HIV/AIDS, sehingga dibutuhkan konseling untuk kepatuhan meminum obat, agar pasien mengalahkan bosan dan tetap menjalani perawatan. 
Pelayanan bimbingan dan konseling Islam yang diberikan konselor kepada pasien dalam meningkatkan kesehatan mental pasien yaitu: pertama, membantu pasien menemukan makna dari penyakit. Konselor membantu menanamkan pada diri pasien bahwa penyakit yang dialaminya sebagai ujian, menguji kesabran, serta keikhlasan untuk meningkatkan derajat seorang hamba di hadapan Tuhannya. Penjelasan seperti ini lebih mudah diberikan kepada mereka yang tertular HIV/AIDS dari pasangannya (suami atau istri) dan mereka yang tertular karena transfusi darah atau penggunaan alat medis yang tercemar virus tersebut. Sementara bagi pasangan yang membawa virus atau mereka yang melakukan tindakan berisiko terkena HIV/AIDS maka konselor akan menanamkan pada dirinya bahwa penyakit yang dialaminya sebagai suatu peringatan agar pasien menyadari perbuatannya yang menyimpang sehingga dapat memperbaiki diri. 45

Kedua, menguatkan harapan yang realistis kepada ODHA. HIV/AIDS memang hingga sekarang belum bisa disembuhkan, namun ada obat yang dapat memutus pertumbuhan virus tersebut. Obat yang diminum ODHA harus diminum seumur hidup, hal demikian menjadi suatu permasalahan pada diri ODHA karena mereka akan mengalami kejenuhan. Konselor dalam hal ini harus bisa membimbing ODHA dalam kepatuhan minum obat seumur hidup, sehingga ODHA dapat menjalani hidup lebih lama lagi.

Ketiga, memberikan dukungan emosional dan spiritual yang dapat menumbuhkan motivasi. Penyakit yang dialami ODHA merupakan masalah besar dalam hidupnya, karena HIV/AIDS merupakan penyakit yang hingga sekarang belum bisa disembuhkan. Masyarakat menganggap bahwa penyakit tersebut merupakan penyakit yang tercela disebabkan dari perilaku menyimpang. Hal ini membuat kesehatan mental ODHA semakin terganggu. ODHA dengan demikian sangat membutuhkan dukungan dan perhatian untuk menghadapi penyakit yang dideritanya.

Keempat, memberikan bimbingan agar pasien selalu berpikir positif. Kasus yang dialami ibu yang belum memiliki anak, dia merasa takut, cemas, dan khawatir karena dengan penyakit yang dialami dia tidak bisa punya anak. Konselor selalu memberikan bimbingan agar dia selalu berpikir positif dan menanamkan perasaan positif, karena selain ada VCT dan PITC juga ada PMTCT. PMTCT (Prevention of Motherto Child Transmission) yang merupakan dialog antara konselor dengan pasien bagi penderita HIV/AIDS yang merencanakan punya anak. 
Kelima, membantu ODHA dalam menanamkan rasa percaya diri serta membantu meningkatkan kualialitas hidup. Konselor selalu menanamkan bahwa pasien yang terkena HIV/AIDS untuk selalu berpikir yang positif, bahwa dia bukanlah orang yang rendah atau hina, dan bahkan orang di sekitar masih membutuhkan dirinya. ${ }^{46}$

\section{Analisis Problem Kesehatan Mental dan Pelayanan Bimbingan dan Konseling Islam dalam Menumbuhkan Kesehatan Mental}

Metode pelayanan bimbingan dan konseling Islam yang diberikan pada pasien umum dengan pasien khusus memiliki perbedaan, karena orang dengan HIV/AIDS membutuhkan pendekatan yang berbeda dengan pasien yang sakit pada umumnya. ODHA akan lebih apatis dan lebih memilih untuk mengasingkan diri daripada bergaul dengan individu lain. Bimbingan dan konseling Islam yang dilakukan pada dasarnya seperti bimbingan pada umumnya, yaitu mulai dari tahap awal, tahap inti, tahap akhir, kemudian dilakukan analisis bersama antara pasien dengan pembimbing.

Metode pelayanan bimbingan dan konseling Islam yang telah dijelaskan dikuatkan dengan pendapat Nursalam dan Kurniawati, bahwa bimbingan dan konseling Islam ini memiliki keunikan dibandingkan dengan konseling lain. Keunikan ini di antaranya yaitu: membutuhkan pengetahuan yang luas tentang infeksi menular seksual (IMS) dan HIV/AIDS, membutuhkan pembahasan mengenai praktik seks yang bersifat pribadi, membutuhkan pembahasan tentang kematian atau proses kematian, membutuhkan kepekaan konselor dalam menghadapi perbedaan pendapat dan nilai yang mungkin sangat bertentangan dengan nilai yang dianut oleh konselor itu sendiri, membutuhkan keterampilan pada saat memberikan hasil HIV yang positif, serta membutuhkan keterampilan dalam menghadapi kebutuhan pasangan anggota pasien. ${ }^{47}$

Jenis pelayanan konseling di klinik VCT yaitu mulai dari konseling permulaan, konseling pra tes, konseling pasca tes, serta konseling berkelanjutan. Pendapat ini didukung oleh Nursalam dan Kurniawati.

46 Wawancara dengan Konselor VCT Khusnul Khotimah, tanggal 13 Oktober 2015

47 Ema Hidayati, "Dimensi Spiritual dalam Praktek Konseling Bagi Penderita HIV/AIDS di Klinik Voluntary Conseling Test (VCT) Rumah Sakit Panti Wiloso Citarum Semarang", Laporan Penelitian, (Semarang: Lembaga Penelitian IAIN Walisongo, 2012), hlm. 35 
Nursalam dan Kurniawati berpendapat bahwa konseling pada pasien HIV/AIDS beberapa tahap, yaitu: konseling permulaan, konseling pra tes, dan konseling pasca tes. ${ }^{48}$ Pertama, konseling permulaan. Konseling dilakukan dengan tujuan untuk memberikan arahan kepada individu yang dirasa memerlukan tes HIV. Tujuan dari konseling ini yaitu agar pasien memahami kegunaan tes tersebut, pasien dapat menilai resiko dan mengerti persoalan dirinya, pasien dapat menurunkan kecemasan, dapat membuat rencana penyesuaian diri dalam kehidupan, serta dapat memilih dan memahami apakah akan melakukan tes darah atau tidak.

Kedua, konseling pra tes. Konseling pra tes dilakukan secara individu dengan pasien. Konseling dilakukan dengan adanya persetujuan dari pasien. Konseling bertujuan membantu pasien mempersiapkan diri untuk pemeriksaan serta memberikan dukungan pada pasien, apapun hasil tes pasien harus bisa menerima dan memasrahkan semua pada Allah swt. Ketiga, konseling pasca tes. Konseling pasca tes merupakan kegiatan konseling yang harus diberikan setelah hasil tes diketahui, baik hasilnya positif maupun negatif. Konseling pasca tes ada dua macam, yaitu untuk hasil yang nonreaktif (negatif) dan hasil reaktif (positif). Konseling pasca tes bagi pasien dengan hasil non reaktif bertujuan untuk mengarahkan agar pasien tidak melakukan atau menjaga dari hal yang menyimpang atau berpotensi untuk tertularnya penyakit HIV/AIDS. Konseling pasca tes dengan hasil reaktif didukung oleh Nursalam dan Kurniawati. Nursalam dan Kurniawati berpendapat bahwa konseling bagi pasien HIV/AIDS positif bertujuan untuk membantu klien membantu dan memahami hasil tes secara tepat, menurunkan masalah psikologis dan emosi, menyesuaikan kondisi dirinya dengan infeksi, serta menyusun pemecahan masalah. Konseling pasca tes dengan hasil negatif bertujuan untuk memahami arti periode jendela, mengambil keputusan tes ulang atau tidak, mengurangi resiko tertularnya HIV/AIDS dari perilakunya. ${ }^{49}$ Keempat, konseling berkelanjutan. Konseling berkelanjutan bertujuan memfasilitasi ODHA. Mereka dapat menceritakan apa yang dialami serta keluhan yang dirasakan. Pasien dengan hasil reaktif akan ditindaklanjuti dengan pengobatan. Pengobatan yang dilakukan pasien HIV/AIDS dilakukuan seumur hidup, karena belum ada obat untuk menyembuhkan pasien HIV/AIDS.

48 Nursalam dan Ninuk Dian Kurniawati, Asuhan Keperawatan pada Pasien Terinfeksi HIV/AIDS, (Jakarta: Salemba Medika, 2009), hlm. 76-78

${ }^{49}$ Nursalam dan Ninuk Dian Kurniawati, Asuhan Keperawatan pada Pasien Terinfeksi HIV/AIDS, (Jakarta: Salemba Medika, 2009), hlm. 74 
Konseling yang diberikan bertujuan untuk memahami kegunaan tes HIV/AIDS, membantu klien menilai risiko dan mengerti persoalan yang dihadapi, membantu klien menurunkan kecemasan, dan membantu klien membuat rencana penyesuaian diri. Konseling pasca tes yang dilakukan klinik VCT RSI Sultan Agung menggunakan konsep Nursalam dan Kurniawati. ${ }^{50}$ Langkah-langkah konseling diarahkan membantu pasien menghadapi masalah seperti penolakan, perasaan tidak aman, merasa bersalah, rendah diri, merasa benci dengan orang yang menulari, tidak berdaya, marah, merasa cacat, tidak berguna, cemas, konfusi, takut, pola seksual tidak efektif, isolasi sosial, dan sebagainya.

\section{Simpulan dan Rekomendasi}

ODHA merupakan individu yang mengalami permasalahan tidak hanya dari segi fisik saja, namun mereka juga mengalami beban mental dalam dirinya. ODHA dengan demikian tidak hanya membutuhkan pelayanan dari segi klinis saja, tetapi juga membutuhkan penanganan holistik. Klinik VCT RSI Sultan Agung Semarang dalam hal ini merupakan bentuk dari upaya menangani kebutuhan mereka yang terkena HIV/AIDS. Klinik VCT memiliki tujuan untuk mencegah penularan HIV, memberikan dukungan moral, informasi kesehatan, memberikan dukungan untuk selalu mendekatkan diri pada Allah, serta dukungan lainnya kepada ODHA, keluarga, dan lingkungan. Kajian ini dengan demikian membantu dalam melengkapi penanganan pasien HIV/AIDS, persoalan-persoalan dakwah Islami, serta membantu menangani problem masyarakat.

Untuk meningkatkan kesehatan mental pada diri ODHA diperlukan pelayanan bimbingan dan konseling Islam dalam meningkatkan motivasi hidup bagi ODHA; meningkatkan konseling kepada keluarga pasien agar dapat menerima dan memberi dukungan kepada ODHA; meningkatkan sosialisasi HIV/AIDS pada masyarakat luas khususnya pada remaja dan mereka yang berpotensi terkena HIV/AIDS agar mengenal bahaya, cara penularan HIV/AIDS sehingga ODHA tidak didiskriminasikan dan tidak mengalami kesehatan mental yang terganggu; serta diperlukan pendampingan lanjutan tentang pengembangan dan pemberdayaan potensi korban dan keluarga dengan HIV/AIDS.

50 Nursalam dan Ninuk Dian Kurniawati, Asuhan Keperawatan pada Pasien Terinfeksi HIV/AIDS, (Jakarta: Salemba Medika, 2009), hlm. 78-79 


\section{DAFTAR PUSTAKA}

Amin, Samsul Munir, Bimbingan dan Konseling Islam, (Jakarta: AMZAH, 2010).

Daradjat, Zakiah, Islam dan Kesehatan Mental, (Jakarta: CV. Haji Masagung, 1988).

Daradjat, Zakiah, Pendidikan Agama dalam Pembinaan Mental, (Jakarta: Bulan Bintang, 1982).

Departemen Agama RI, Al-Qur'an dan Terjemahnya, (Bandung: CV Penerbit J-ART, 2004).

Faqih, Ainur Rahim, Bimbingan dan Konseling dalam Islam, (Yogyakarta: UII Press, 2001).

Hallen A., Bimbingan dan Konseling, (Jakarta: Quantum Teaching, 2005).

Harahap, Syaiful W., Pers Meliput AIDS, (Jakarta: Pustaka Sinar Harapan, 2000).

Hawari, Dadang, Konsep Agama (Islam) Menaggulangi HIV/AIDS, (Yogyakarta: Dana Bhakti Primayasa, 2002).

Hidayati, Ema, Dimensi Spiritual dalam Praktek Konseling Bagi Penderita HIV/AIDS di Klinik Voluntary Conseling Test (VCT) Rumah Sakit Panti Wiloso Citarum Semarang, Laporan Penelitian, Semarang: Lembaga Penelitian IAIN Walisongo, 2012.

Kartono, Kartini dan dr. Jenny Andari, Hygine Mental dalam Islam, (Bandung: CV. Mandar Maju, 1989).

Kartono, Kartini, Hygiene Mental, (Bandung: Mandar Maju, 2000).

Langgulung, Hasan, Teori-Teori Kesehatan Mental, (Jakarta: Pustaka AlHusan, 1986).

Maryani, Lidya dan Riski Muliani, Epidemiologi Kesehatan Pendekatan Penelitian,(Yogyakarta: Grahana Ilmu, 2010).

Musnamar, Thohar, Dasar-Dasar Konseptual Bimbingan dan Konseling Islam, (Yogyakarta: UII Press, 1992).

Naing, Amaya Maw dkk, Modul Pelatihan Konseling dan Tes Sukarela HIV (Voluntary Conseling and Test/VCT) untuk konselor profesional, Departemen Kesehatan RI Direktoral Jendral Pelayanan Medik 
Direktorat Jendral Pemberantasan Penyakit Menular dan Penyakit Lingkungan, 2004.

Nursalam dan Ninuk Dian Kurniawati, Asuhan Keperawatan pada Pasien Terinfeksi HIV/AIDS, (Jakarta: Salemba Medika, 2009).

Prayitno dan Erman Amti, Dasar-Dasar Bimbingan dan Konseling, (Jakarta: Rineka Cipta, 1999).

Riyadi, Agus, Bimbingan Konseling Perkawinan, (Yogyakarta: Ombak, 2013).

Sa'abah, Marzuki Umar, Perilaku Seks Menyimpang dan Seksualitas Kontemporer Umat Islam, (Yogyakarta: UII Press , 2001).

Semiun, Yustinus, Kesehatan Mental 1, (Yogyakarta: Kanisius, 2006).

Semiun, Yustinus, Kesehatan Mental 3, (Yogyakarta: Kansius, 2006).

Sutadipura, Balnadi, Kompetensi Guru dan Kesehatan Mental, (Bandung: CV. Angkasa, 1986).

Sutoyo, Anwar, Bimbingan dan Konseling Islam Teori dan Praktik, (Semarang: Widya Karya, 2009).

Waligito, Bimo, Bimbingan dan Konseling (Studi \& Karir), (Yogyakarta: ANDI, 2004).

Winkel dan Sri Hastuti, Bimbingan dan Konseling di Institusi Pendidikan, (Yogyakarta: Media Abadi, 2007).

Wawancara dengan Konselor VCT Khusnul Khotimah, tanggal 1 September 2015.

Wawancara dengan Konselor VCT Khusnul Khotimah, tanggal 15 September 2015.

Wawancara dengan Konselor VCT Khusnul Khotimah, tanggal 13 Oktober 2015.

Wawancara dengan Konselor VCT Khusnul Khotimah, tanggal 22 Oktober 2015.

Wawancara dengan Report and Record Ziadah Mustafa, tanggal 6 Juni 2015.

Wawancara dengan Report and Record Ziadah Mustafa, tanggal 1 September 2015. 